\title{
Cross-Culture Consideration in Business Event: A Perspective of Trade Fairs between China and Germany
}

\author{
Xuehui Zeng \\ Event Management Department \\ Shanghai Polytechnic University, SSPU \\ Shanghai, China
}

\begin{abstract}
This paper outlines some of the basic culture elements and discusses the related theoretical and practical issues in designing international business event in China or in Germany. The aim is to prepare the trade fair organizers for better communication in order to avoid the misunderstanding caused by cultural differences. The paper first analyzes the different characteristics of the two countries based on the theory of Lewis Cross Cultural Communication Model--Dimensions of Behavior. In addition to make a contrast on the expectations of different culture groups in the event, the paper also compares the German business cultural standards with the traditional Chinese business culture and the practical etiquette when doing business in China and Germany. The research indicates that Chinese business culture is deeply influenced by Confucianism and collectivism. Germany also has its own culturally-specific behavior typical of the linear-Active behavior category group. The paper gives a new perspective for the organizers of both sides to survive a business event either in China or in Germany.
\end{abstract}

Keywords-Cross-Culture consideration; Business Event; Trade Fairs; China and Germany

\section{INTRODUCTION}

Trade fairs are a key driver of international trade in goods and services. They are important marketing instruments in B2B communications and they intensify competition and trade in nearly all economic regions around the globe. Germany is the world's leading host for international trade fairs and China is a potential leading partner in the trade fair market. According to the Global Association of the Exhibition Industry (UFI), there are around 1,200 exhibition venues worldwide and 31,000 exhibitions a year. Germany accounts for nearly 10 percent of the world's exhibition market [1]. Trade fairs are by far the most important instrument in B2B communications. This is one of the main reasons why the exhibition business is one of the leading service sectors in Germany. It encompasses all companies, associations and persons that organize fairs or provide services for organizers and exhibitors. The sector also enjoys a high status internationally. Germany is China's biggest trading partner and technology exporter in Europe and the amount of German investment in China ranks second among European countries, after the United Kingdom [7]. China is Germany's largest trading partner, superseding the United States since 2017 [2]. Germany is the world's leading host for international trade fairs. Two thirds of the global trade fairs for a variety of industries take place in Germany. China is one of the world's fastest developing economies and its leading trade fairs offer prime access to the market [3]. Exhibiting at fairs and participating in or hosting events in China or Germany provide the opportunity to present the products or services directly to customers and business partners of both countries. Crosscultural communication is very important for both countries to reach a win-win cooperation.

\section{THE LEWIS CROSS CULTURAL COMMUNICATION MODEL--DIMENSIONS OF BEHAVIOR}

The globalization of world business in the last 5 decades has heralded in an era when cultural differences have become vitally important to leaders, managers and executives in the world's international and multinational companies. Richard Lewis Communications was founded by Richard D. Lewis, one of Britain's foremost linguists and Cross Cultural Theorists. The Lewis Cross Cultural Communication Model shows how people from different cultures vary in their concepts of time and space, handle interpersonal distance, silence, and eye contact, how their communication styles are reflected in the language patterns they use, how they view the truth, as absolute or negotiable i.e. modifiable according to the situation, what their values, attitudes and world views are. According to Richard Lewis "Cultural behavior is the end product of collected wisdom, filtered and passed down through hundreds of generations as shared core beliefs, values assumptions, notions and persistent action patterns".[4] In other words, culture is a collective programming of the mind that distinguishes the members of one human group from another." The behavior we accept as normal is actually formed from learned and inherited beliefs based on our religious upbringing, ethnic, generational, class, and gender programming, as well as the educational socialization and the professional ethics we have been taught and accepted. $\mathrm{He}$ came to the conclusion that humans can be divided into 3 clear categories on BEHAVIOUR. He named his typologies Linearactive, Multi-active and Re-active. Lewis plots countries in relation to three categories, see table 1 . 
TABLE I.

The Lewis Cross Cultural Communication Model--Dimensions of BeHAVIOR

\begin{tabular}{|c|c|c|}
\hline Category & Characteristics & Typical Countries \\
\hline Linear-Actives & $\begin{array}{c}\text { Task-oriented, highly-organized planners, who complete action chains } \\
\text { by doing one thing at a time, preferably in accordance with a linear } \\
\text { agenda. }\end{array}$ & Germans and Swiss \\
\hline Multi-Actives & $\begin{array}{c}\text { Emotional, loquacious and impulsive people who attach great } \\
\text { importance to family, feelings, relationships, people in general. They } \\
\text { like to do many things at the same time and are poor followers of } \\
\text { agendas, planning their priorities not according to a time schedule, } \\
\text { but according to the relative thrill or importance that each } \\
\text { appointment brings with it. }\end{array}$ & $\begin{array}{c}\text { Italians, Latin } \\
\text { Americans and Arabs }\end{array}$ \\
\hline Re-actives & $\begin{array}{c}\text { Good listeners, who rarely initiate action or discussion, preferring } \\
\text { first to listen to and establish the other's position, then react to it and } \\
\text { form their own opinion. Those cultures that prioritize courtesy and } \\
\text { respect, listening quietly and calmly to their interlocutors and reacting } \\
\text { carefully to the other side's proposals. }\end{array}$ & $\begin{array}{c}\text { Chinese, Japanese and } \\
\text { Finns }\end{array}$ \\
\hline
\end{tabular}

We can see in Table 1, Germany is in the linear-active group and China is in the re-active group which means that the two countries are quite different in cultural behaviors. Based on the Lewis Cross Cultural Communication Model , expectations at meetings and events is shown as follows. See Table 2.

TABLE II. EXPECTATIONS OF LINEAR-ACTIVES AND RE-ACTIVES AT EVENT

\begin{tabular}{|c|c|}
\hline Linear-actives & Re-actives \\
\hline Agenda & Formality \\
Scientific truth and facts & Respect \\
Get to the point & Seeking harmony \\
Decisions & Approach issues slowly \\
Action plan & Few immediate decisions \\
Progress & Few new ideas \\
Budgets & Finding people they can work \\
Entertainment(show) & with \\
& Entertainment(sharing \\
& important) \\
\hline
\end{tabular}

\section{UNDERSTANDING GERMAN BUSINESS CULTURAL STANDARDS}

Culturally-specific behavior can be explained on the basis of cultural standards [5]. This can aid in understanding what would otherwise be irritating, unusual and strange events. This knowledge is therefore an important basis for constructive cooperation between members of different cultures. The most important German cultural standards are:

Focus on the task: The task is the central and dominant issue in all business interactions and also determines the style of communication. The relationship level assumes a more subordinate role in professional life. Germans usually think that operating at the task level should form the basis of all business contacts.

Value of structures and rules: In German companies, there are countless rules, regulations, procedures and processes. German business people prefer contracts and written agreements of all types. The existence of these things and their tight and consistent application, the adherence to them and the rigid consequences, or even penalties, for not complying with them are in stark contrast to other cultures.

Reliability and avoidance of uncertainty: Consistency and reliability are seen as especially important German traits. Members of the German culture have a high tendency to avoid uncertainty. They therefore develop binding rules and structures in order to foster certainty in dealings with each other.

German punctuality: The approaches described above have a strong impact on the relationship with regard to time. Appointments are precisely planned and it is expected that times which are set are adhered to. Punctuality is a matter of good manners.

Separation of private and public spheres: Germans exercise a strict separation between the various spheres of their life. They clearly vary their behavior with other people depending on the sphere of their life (private or business) in which they have contact with an individual as well as the closeness of the relationship (business partner or friend). This frequently leads to Germans in business or public life being seen by members of other cultures as very remote and cold and even as overtly unfriendly.

Directness of communication: Germans communicate very directly and explicitly. They formulate important statements directly and openly. They can appear rude and threatening without meaning to or even noticing it. In return, they do not easily recognize and respond to verbal subtleties such as indirect hints, messages 'between the lines' and many nonverbal signals. They can therefore often miss the decisive content of an interaction. 


\section{UndERSTANDING TRADITIONAL CHINESE BUSINESS CULTURE}

With increasing globalization comes the need for more and more people to do business with the Chinese. While language is important in bridging an intercontinental relationship, the cultural expectations behind the language are even more essential. Developing insights into the Chinese business culture will help avoid miscommunication and potential misunderstandings. China is influenced deeply by Confucianism. Confucianism places a heavy emphasis on interpersonal relationship and the importance of respect for rulers, family orders and social harmony. It's a national philosophy and system of beliefs. Even over 2,500 years on, Confucian beliefs are still ingrained in mainstream ethics.[6] Chinese people are family-oriented, family orders and relationships are of great importance. The most important traditional Chinese business culture is social connection (Guanxi) and face issues.

Guanxi. Family relation extends to social connection that is Guanxi network. Guanxi combines aspects of face, obligation, reciprocity, and hierarchy. Simply put, it is a network of relationships that carries a certain expectation of mutual benefit. A Guanxi network is made up of people one can count on and trust, who can pull strings and arrange for extra help. First and foremost, these people are family, then perhaps classmates or colleagues. In granting a favor or help, there is the unspoken expectation of reciprocity, and the receiver is somewhat in debt until the favor is returned.

Face. The Chinese concept of face is similar to the Western concept of face, but it is far more important in China. Face is associated with honor, dignity, and a deep sense of pride. Causing someone to lose face, even if the offense was unintentional, could cause serious damage to a relationship. The collective nature of China society means that the loss of face affects not only the individual but also his or her network. In addition, the concept of face is important in the business world. In China, where rank and hierarchy are more important than they are in most Western societies, sending someone of lower status to receive a high-ranking guest could cause the guest to lose face. Similarly, seating someone of high rank inappropriately at a banquet, where guests are seated according to rank, could damage that person's sense of honor and dignity. Face is one of the key aspects of Chinese culture. A Chinese person always wants to save face, never lose it. In order to "give face," pay attention to elders and rankings, especially when it comes to government officials.

The art of subtle communication. Face issue also influences the way of communication. Comprehending the differences between German and Chinese communication styles is crucial for business success. Germans tend to use a direct communication style in which "yes" means "yes" and "no" means "no." In China, however, because of sensitive face issue, it is impolite for the Chinese people to give negative answers directly. The blunt "No" should be replaced by the euphemistic "maybe" or "we'll think about it". A direct "no" would cause the person whose proposal is being rejected to lose face, so an indirect style of communication prevails. Thus, a nod of the head could mean either "yes" or "I hear you, but I disagree," and silence does not necessarily imply consent. For instance, "We will think this over again", "That is an interesting idea", or "It's not very convenient" are actually indirect ways of saying "no." The Western businessperson should learn to recognize them and what they really mean. The Chinese complex character "listen" is comprised of the ear, eye, and heart radicals, implying that listening uses not only ears but also the heart and eyes.

The Chinese banquet: A formal Chinese banquet is something that most businesspeople in China will experience. The seating arrangement is paramount. A guest should always wait for the host to seat him or her, because seating arrangements are based on rank or importance. When toasting, a general rule of thumb is to wait until the host offers the first toast and then reciprocate,

\section{BUSINESS ETIQUETTE COMPARISON BETWEEN CHINA AND GERMANY}

No doubt, traditional culture standards of both countries lead to practical etiquette in doing business. By comparing the major differences will help both side have better communication, better understanding, avoid misunderstanding and finally show respect to each other.

Greetings and introduction; Nodding and smiling are very common greetings in both countries. In China, shaking hand should be with due force and should not be too short or too long. In official business meetings in China, people of higher social positions are waiting to be introduced to others in the group and stretch out hand first to greeting the others. If you are invited to a business meeting in Germany, you will mostly get picked up by your business partner at the main gate of the company. That means you are not being introduced by someone. You can introduce yourself directly. German people always use one hand and does not matter if it is the right or the left one to greet each other. The handshake with both hands, as it common practice in China, does not exist at all in Germany. In Germany, the one arrive first enter s the room first. Not so much value is put on the hierarchy.

Addressing. Regarding a courteous address, most people should be addressed with their rank and titles followed by their surname. For example, Manager Wang, Prof. Zhang. If you are not sure about the precise titles, you can also use Sir, Mr., Miss or Madam instead. Surname plus title is a polite way to address people. In Germany, the most common way is to say your title (e.g. Prof. Dr.), your full name, your job position and your company.

Business cards. Exchanging business cards is another key part of introductions. A business card is regarded as an extension of the person, so treat the business card carefully. The polite thing to do is accept the business card with both hands and look at it carefully as you do so. This gesture of respect does not exist in Germany. That means that you can exchange the business card in the way you want. Either with one or both hands.

Small talk. Chinese people, much like English-speaking peoples around the world, often open conversations with small talk, which can break the ice. Questions like "Have you eaten"? 
or "Where have you been?" are common ice breaking talks in Chinese culture. Thus, don't feel the need to go into detail in your answer. These questions are just like "how are you?" in English-based culture. In Germany, the private and the business are often strictly separated. If a business meeting is called, it is directly and exclusively about business.

Seat and order for dining. During a Chinese dinner, there is a certain order in which people must sit down. You can expect more senior business people to be seated first, then just wait for the Chinese people to show you your seat.

Accepting gifts. When you receive a gift, just as when you receive a business card, accept it with two hands. Don't open the gift immediately unless the person who gives it to you requests that you open it right away.

Giving gifts. Giving gifts to your Chinese colleagues is a kind of art. Gifts should not be too expensive. And if your business counterparts are government officials, make sure you don't give them a reason to mistake your kindness as bribery. Giving gifts. The concepts of humility and face are also connected to Chinese gift-giving etiquette. For instance, although it is completely appropriate in Germany to open a gift in front of the gift-giver, such an action is generally considered impolite in China. What if, for example, a guest opened a gift that was much less valuable than expected in front of the host? This could cause embarrassment, discomfort, and the possible loss of face for both the recipient and the giver. It is better to accept the gift with two hands, thank the person, and place it off to the side. In this way, no feelings are hurt and no face is lost. In Germany, it is normally not to bring a gift to a business partner. Otherwise, the accusation of bribery or distortion of competition is very quickly in the room with expensive expenses.

Negotiation. Contract and commitments to Linear-actives are binding and final, while to Re-actives are a statement of intent which must be re-negotiated if circumstances change. Chinese negotiations are process-oriented. Chinese prefer to do business with the friends, therefore it takes time to make friends. Doing business is based on relationships, strong relationship with a network have an influence on business. Therefore contracts are not considered the closing of the business deal, it can be modified and changed anytime.

\section{CONCLUSION}

Entering China with even a rudimentary understanding of Chinese culture and business etiquette can help business interactions go more smoothly. Because China is a complex country to navigate, particularly for the newcomer, knowing how to behave at a banquet or what gift to give your Chinese host help prepare a Westerner for doing business in China. Thus, though it is essential for foreign businesspeople to have a deep understanding of face, Guanxi, and the more subtle aspects of Chinese culture when meeting with older Chinese colleagues, those concepts are slightly less important when interacting with younger urbanites. The rising importance of sound business principles and credentials makes it easier to accomplish things without relying exclusively on Guanxi connections in contemporary China. Guanxi and face are interconnected and are both critically important in understanding Chinese business practices, A generational and geographical gap in the importance of these cultural concepts is emerging in China today. Understanding several key cultural concepts is useful in personal and business dealings. Knowing Chinese etiquette, from proper banquet behavior to gift-giving and business card exchange, can only help to enhance business relations and avoid embarrassing situations. Across the globe, even what might be considered the "fundamental" of event organizing differ from region to region: meal times, hours of work, methods of learning and decision-making, interpersonal relationships, the role of the family, and attitudes time and what is ethical are just a few areas of diversity. But success will follow those event professionals who take the time and trouble to learn about the people with who they will work and the places they will visit. And it is no exaggeration to say that the events industry is in the vanguard of the movement. Event professionals are the movers who bring people together, who facilitate communication and encourage relationships. We have an important role to play. This is why research is always necessary before doing business anywhere in the world.

\section{ACKNOWLEDGMENT}

This research was supported by the Tourism Management Discipline Research Program funded by Shanghai Polytechnic University, P.R. China (Grant NO. XXKPY1607).

\section{REFERENCE}

[1] Surveys and Studies, Euro Fairs Statistics 2017 (September 2018) by UFI.

[2] Surveys and Studies, The Trade Fair Industry in Asia - 14th Edition (2018) - Leaflet by UFI.

[3] Herald Globe. Archived from the original on 2014-07-14. Retrieved 5 July 2014.

[4] When Culture Collide, leading across cultures, 3rd edition by Richard D. Lewis, Nicholas Berkley, International, Boston. London.

[5] Guide-to-German-culture_-costums-and-etiquette-Aug-2016.pdf.

[6] Chinese Business Etiquette: Stone Bridge Press 2012.

[7] German's Trade Fairs Market by AUMA,2018/.

[8] International Manual $1^{\text {st }}$ edition published by Convention Industry Council, June 2005. 